\title{
The concept of health in Collective Health: contributions from social and historical critique of scientific production
}

| ${ }^{1}$ Marcelo José de Souza e Silva, ${ }^{2}$ Lilia Blima Schraiber, ${ }^{3}$ André Mota |

Abstract: This study aimed to understand the concept of health within Collective Health. Our analysis starts from Marxism as a theoretical reference, both to define what is a "concept" and to understand the critical thinking of Collective Health. As empirical research the bibliographic production of the main journals that bring together Collective Health publications as a knowledge area was used, which resulted in 34 papers that somehow treated the concept of health, even if it was not the main object of the study. From this analysis we identified at least three different modalities of definitions, which varied both in the referential basis used to apprehend and analyze empirical realities concerning health, and in the conceptualization of social that could be in this analysis. We have also identified that the papers ranged between a production that was strictly descriptive of these empirical realities and strictly theoretical essays, rather than to produce a concrete (empirical) thought based on the elected definition of social. It was concluded that within Health Collective the concept of health has been taken, in general, either as a notion (a partial approximation of the object) or as a motto, from an ethical-political engagement that ends up relegating the theoretical-conceptual contribution to the background.

> Keywords: Collective Health; concept formation; health; knowledge; work.

\author{
1 Universidade Federal do Paraná, \\ Saúde Coletiva. Curitiba-PR, Brazil \\ (marcelojss@gmail.com). \\ ORCID: 0000-0002-4862-9460 \\ ${ }^{2}$ Universidade de São Paulo, \\ Medicina Preventiva. São Paulo- \\ SP, Brazil (liliabli@usp.br). \\ ORCID: 0000-0002-3326-0824 \\ ${ }^{3}$ Universidade de São Paulo, \\ Medicina Preventiva. São Paulo-SP, \\ Brazil (andremota13@gmail.com). \\ ORCID: 0000-0002-5697-8628
}




\section{Introduction}

World War II was a conflict that involved all countries in the world, either directly or indirectly, with incalculable losses, both in material terms and in terms of human lives ("because civilians and civil life became guaranteed strategic targets") (HOBSBAWM, 2011, p. 56). After its conclusion, the World Health Organization (WHO) was founded, in 1948. This international organization would set a definition of health which, by considering it not only as the absence of disease, but as a total physical, psychic and social well-being, sought to overcome the biomedical conception in use up to that point. Over the years, new definitions were put forward, in search of alternatives both to the biomedical conception and to the WHO's definition.

In the 1970s and 1980s, in Brazil, a movement emerged under the name Collective Health, something which, according to Schraiber (2015), can be considered a Brazilian construction due to its peculiarity in intertwining the scientific field with the political struggle for redemocratization following the military dictatorship, culminating in the integration between Health Reform and Medicine Reform, based on the principle of integrality in health, incorporated due to the use, in its construction, of different disciplines, but especially the Social Sciences, Humanities and Philosophy. This aspect is reiterated both in Osmo and Schraiber (2015) and in Paim and Almeida Filho (1998, p. 310), when they point to the necessary "overcoming of the dominant biologism, the naturalization of social life, its submission to clinical practice and its dependence on the hegemonic medical model."

Thus, we consider that Collective Health is, currently, a social space which brings together critical approaches and studies on this subject. We therefore believe that it is a more developed space with regard to this discussion, containing the most elaborate contributions to date. It is the space that encompasses critical analyses with regard to the biomedical construction of Medicine and that seeks to weave other relationships between health and society. We are interested in understanding how this conceptual construction regarding health has taken place in the Collective Health scientific production working from the Marxist theoretical framework, to which we turn in the following section. This is both so we can define what a "concept" is and to carry out a critical analysis of how the object health has been addressed in terms of its conceptualization in Collective Health, thus seeking to enrich this debate. 


\section{The concept as a thought concrete}

We view concepts as the product of a reflexive formulation, a method which consists of starting from the particular-concrete, the phenomenon which is part of the social, in order to reach the more universal categories that capture the complexity of this particular-concrete through determinations that lead the phenomenon to be a part of that whole. These determinations are the connections between the particular reality under examination and the social whole from which it was removed in order to be an object of study (MARX; ENGELS, 2009; KOSIK, 2011; VIGOTSKI, 2009; ILYENKOV, 2008). Thus, the dimension of the concrete is both the endpoint and the starting point. However, these concepts will not be the same, because the endpoint is a new concrete: that which is explained and may be understood with all those determinations that connect it to the social; an endpoint, therefore, which is now at a superior level of formulation, no longer that apparently simple concrete, and which, as a form of comprehension, is still limited and chaotic, as in the beginning of its reflexive analysis. Furthermore, knowledge of these connections, which account for the concrete configuration of the part itself, occurs through the movements of the reflexive formulation between the empirical reality and the reference for the social we adopt, the understanding that it is this social in which the part chosen to be studied is inserted. These movements enable us to progressively reach the social determinations of that part's concrete configuration; with each new movement (praxis-theory-praxis), one achieves an understanding of the phenomenon, the particular, with an increasingly rich reflection, with a greater understanding of the existing determinations.

Furthermore, as a historical reality, this movement does not end with the constructed abstraction, but is continuously confronted with empirical reality, over time. As Lefèbvre (1983, p. 98, emphasis in the original) states: "Dialectical relativism admits the relativity of our knowledge, not in the sense of denying the objective truth, but in the sense of a perpetual overcoming of the limits to our knowledge".

This way of formulating a concept is a method that assumes the existence of an uninterpreted concrete reality, in addition to a practical objective activity of the social human being that is developed independently of thought and an immediate sensory form of reflection of the objective concrete reality onto the consciousness. This is "the only method by which thought can reproduce in the concept, in the 
movement of concepts the historically established concreteness existing outside of and independently from it, a world existing and developing outside of and independently from thought." (ILYENKOV, 2008, p. 158).

We thus apprehend the objective reality through concepts, through abstractions, since, in our analysis, "we cannot make use of microscopes or chemical reagents" (MARX, 2013, p. 78). The concept is produced after all concrete factual characteristics (the casual characteristics) are abstracted, enabling us to reach the object's essence (the simplest and, at the same time, most general cell) in order to understand, from this essence, all particular cases, regardless of the different appearances that they may have. This enables the subject, based on this foundation, to understand the phenomenon in its concreteness, as a concrete reality, a synthesis of multiple determinations (MARX, 2008).

\section{The concept of health in Collective Health}

We carried out a document-based empirical search containing bibliographical production selected from the SciELO database. We chose SciELO because it includes the main Collective Health journals. For the search, we used the following search words in isolation: "health concept", "social determination of the healthillness process" and "global health". Next, we used other search words related to the theme simultaneously: "health-illness process", "health promotion" and "quality of life" in conjunction with "knowledge", "scientific production", "health practices" and "health services". We imposed no restrictions in terms of year of publication and included all articles we identified with the search words above, published between 1978 and 2016. This search yielded a total of 864 articles.

Next, we removed duplicates and selected only Collective Health journals for analysis. The definition of these journals was based on a special volume of Ciência $\&$ Saude Coletiva dedicated to the history of the main Collective Health journals (C\&SC, 2015). They are: Cadernos de Saúde Pública (CSP); Ciência \& Saúde Coletiva (CSC); Revista de Saúde Pública (RSP); Interface - Saúde, Educação, Comunicação (Interface); Revista Brasileira de Epidemiologia (RBE); Saúde e Sociedade (SS); Physis - Revista de Saúde Coletiva (Physis); Revista Brasileira de Saúde Materno-Infantil (RBSMI); Revista Brasileira de Saúde Ocupacional (RBSO); Trabalho, Educação e Saúde (TES); Saúde em Debate (SD); and Revista do Sistema Único de Saúde (RSUS). 
Based on this, we selected, from the 864 articles, 294 for abstract analysis. We read the abstracts in order to identify the articles that explicitly stated they would work with some definition of health, those that used and discussed, or commented upon, a preexisting definition of health that they adopted in the study and those that made use of a given definition of health, even if they did not discuss it. This resulted in 65 articles selected to be read in full.

When reading the full articles, we sought a greater delimitation and precision regarding the definition of health, as the texts had to contain some statement regarding what is health. Based on this evaluation, we were left with 34 articles that affirmed a concept of health, even if that was not the article's main goal. The articles that were finally selected for analysis span the years 1991 and 2015. In the final selection, no articles remained from the following journals: Revista Brasileira de Saúde Ocupacional; Trabalho, Educação e Saúde; Revista Brasileira de Epidemiologia; and Revista do Sistema Único de Saúde.

Of the 34 articles we analyzed, ten sought to analyze health, and the remaining 24 addressed diverse topics. However, only seven sought to discuss a concept of health, with the remaining 27 articles immersed in a more restricted, and even partial, debate of what is health, mostly adhering to preexisting conceptions as an a priori definition, without discussing them. Two polarizing situations are noteworthy: only two articles sought to carry out a well-grounded conceptual formulation of health, while two others conclude in favor of negating this conceptualization.

Thus, based on the analysis of the empirical material, we observed that, in Collective Health, there are two polarizations regarding the concept of health: on the one hand, the majority defends the construction of this concept, with a polysemy of the term existing within a group of studies, as different definitions of what is health emerge; on the other, we find the argument that conceptualizing health is difficult, with studies that deny any such formulation.

\section{The concept of health in Collective Health: the non-possibility of a concept}

Of the documents we analyzed, as mentioned, two argue in favor of the extreme difficulty of formulating a concept of health. Czeresnia (1999, p. 702) states that the "The word, although an elaborated form of expression and communication, is insufficient to grasp reality in its entirety". According to her (1999, p. 703), 
"[h]ealth and falling ill are ways by which life manifests itself. They are unique, subjective experiences; words cannot recognize and signify them entirely", because, she continues, "[h]ealth is not an object that can be constrained within the field of objective knowledge. It does not translate into scientific concept".

Costa and Bernardes (2012) argue that the modern episteme reduces the objectconcept to a pure object, leading disease to be the ontologically-studied object and leading health to become non-disease. According to the authors, based on hermeneutics, health is understood as a minimum ontology, as a murmur on a surface, which inscribes the ways in which it becomes, so that health exists and can be named, but not conceptualized. According to the authors, using Gille Deleuze's simulacrum, health is a given name, it belongs to the order of "is", not of "what is", leading the production of health to directly become the production of life itself and of subjectivities. It seems to us that, to these authors, the abstract is synonymous with a pure form of thought, in opposition to an objective reality that is concrete. The concrete and the abstract would therefore be in an exclusive opposition to one another, so that the concept would seem to constitute a "destruction of the sensually given concreteness, as elimination of a great number of sensually perceived properties for the sake of one of them" (ILYENKOV, 2008, p. 46).

However, in our perspective, despite the historical difficulties and limitations, we must seek to formulate the concept of health. The complexity of human life may be conceptually apprehended, as long as one remains aware that it is a historically relative formulation. And the greatest benefit of seeking conceptualization is precisely overcoming, in each historical moment, the immediately given, that which is only captured through the first perception, in which neither the sociality nor the historicity of the particular reality under examination will be recognized and inscribed as such. We thus affirm not only the importance of seeking to conceptualize health, but the possibility of the existence of such a formulation and, therefore, of the existence of this concept (of health).

\section{The concept of health in Collective Health: health as a notion}

Of the selected documents, nearly half were studies that defined health based on people's perception of this object. Most were interview-based studies. In this group are also the studies that argue that health is a subjective issue. Thus, rather than 
seeking to formulate and defend a specific concept, they take on the representations of the interviewed subjects, portraying these representations as mostly aligned with previous World Health Organization definitions. We can therefore notice that, within Collective Health, great emphasis is placed on analyzing health from an individual perception (even if taken collectively as the social representation of a group), perhaps expressing the value attributed in studies to the personal dimension and also as a reflection of the way in which subjects other than health have been studied within Collective Health. This is because, although social representations are addressed in the studies, they are not the object of reflection regarding what they represent as social, as if the representations were not part of a given sociality - also part of its internal contradictions, which demarcate distinct material situations and cultural universes in the social strata, which would certainly influence representations of health. In these studies, the different representations end up being validated directly as a final explanation of what is health.

Of the articles we analyzed, Bezerra et al. (2005), Freire Júnior and Tavares (2005), Oliveira and Pinto (2007), Figueira et al. (2009), Martins (2010), Torres et al. (2011), Silva and Ramos (2014) classify individuals' perception as belonging to the WHO definition of health. Pereira et al. (1991) and Stanga and Rezer (2015) describe more than one perception, but the WHO's appears as the most common. According to Augusto et al. (2011), Prates et al. (2014) and Oliveira et al. (2015), individuals' definition of health is the absence of disease; while according to Santos et al. (2005), it is the absence of pain. To Shimizu et al. (2015, p. 2907), quality of life is central to perceptions, while Segre and Ferraz (1997, p. 542) and Delfino et al. (2004) argue that health is a subjective issue, without clarifying how the subjective dimension is articulated with the materiality of social life, or if they simply adopt subjectivism (and not subjectivity) as the overriding criterion for constructing this concept.

We should emphasize that the study of individuals' perception of health can provide an important material when describing their conditions of life, giving subjects a voice. However, as Kosik (2011) states, often this perception, this appearance of what a given phenomenon is (health, in our case) is contradictory or even opposed to its essence. Thus, if the analysis remains within this dimension, it remains on the appearance of the objective reality, on the description of concretefactual characteristics, and the naturalized acceptance of this common sense view of individuals' perception ends up limiting our understanding of what health is within, 
and to, the society in which these same individuals are inserted. Without reaching a well-thought-out concept, relative to the sociality of which the representations are part, this type of definition becomes a descriptive discourse on an object's characteristics. It remains, therefore, a notion of health, a formulation which, according to Vigotski (2009) and Ilyenkov (2008) is the first sphere of reflection (social representations), but that does not complete its movement toward the thought concrete (representations as part of the social).

In this group, there are also studies that seek to interpret the social representations under examination with reference to a health definition, such as the one coined by the WHO. These studies are also characterized by their use of a notion of health, but, due to their references to the "well-being" contained in the WHO's definition, they can also be understood as adhering to a motto, a call to cohesion around a more critical view than the mere opposition to disease. But if this motto, on the one hand, seeks to offer an alternative to the biomedical definition of absence of disease in the individual body, on the other, it lacks a more precise construction of the meaning of well-being in its social-historical character, whether to understand physical well-being as part of social life, psychic well-being as equally part of the social, and the properly social (always made relative by references to distinct class situations) relative to the whole of the life in society.

We should further note that if we aggregate this adherence to the group of studies we will turn to next, and which, in a different manner, as we will discuss, also adhered to the WHO definition, we will find that most of the studies regarding the concept of health are either based on, or appeal to, the WHO formulation.

Lastly, Almeida and Trevisan (2011, p. 301) argue that health are "life projects that increase the possibilities of exchanging resources and affection in a network of articulated, flexible relationships, increasing subjects' real participation in society". There is a proposal of something that could be a notion: however, the authors did not pursue this path, failing to obtain even a notion, remaining on a primary idea of health. Furthermore, this conception of health as life projects, without taking into account its sociality, ends up naturalizing society (in this case, the capitalist society) and, without clarifying how this project is articulated with social subjects' greater participation in societal life, one may run the risk of relegating participation to an individual issue, rather than as part of the social. 


\section{The concept of health in Collective Health: health as a motto}

Another group of studies (BYDLOWSKI; WESTPHAL; PEREIRA, 2004; MARCONDES, 2004; SCLIAR, 2007; DALLARI, 2010; FEIO; OLIVEIRA, 2015) took the WHO definition more explicitly as the basis for their analyses. Brugnerotto and Simóes (2009), when analyzing Physical Education curricula, found three definitions: biomedical; broadened, or health promotion; and biological health promotion. However, they conclude that the ideal is to use the WHO definition. These studies do not intend to raise arguments in defense of this definition, that is, it is assumed a priori to be true. Nor are they, as in the previous group, one or more references for explaining the empirical data.

The WHO's definition of health has been criticized practically since its creation, from all kinds of theoretical orientations; however, it is still very hegemonic in common sense views and, as we have seen, within Collective Health. Unlike the previous authors, though still belonging to the same group - health as a motto and not necessarily a concept - in our view, Matumoto et al. (2001, p. 235, emphasis ours) argue that "the collective health's concept of health-disease is demarcated based on the social determination of the health-illness process, unlike that of public health, of causality", while Silva and Ramminger (2014) use Canguilhem's conception of health. In both cases, though respectively pointing to social determination and social normativity as potential explanatory references of health, the authors merely mention these references, without discussing in what way they articulate them with their study objects. From this follows our typification of the adoption of references as an $a$ priori, a motto that is extended to the very health that one wishes to conceptualize.

Another way of defining health found in the documents was the relationship established by the studies between health and individuals' living conditions. To Siqueira and Moraes (2009, p. 2,116), health is defined “in society's historical context and in its development process, encompassing the conditions of nutrition, housing, education, income, environment, work, leisure, freedom, access to and ownership of land and access to health services". And according to Lopes (2005, p. 1,595), health is "the set of integral and collective conditions of existence, influenced by the political, socioeconomic, cultural and environmental context". Associating health to social and/or environmental conditions is an important reflexive element. However, 
once again, in this case, the articulation of particular and concrete conditions to the social whole is not sufficiently explicit, incurring once again on the qualification of the motto, more than of the concept, since it adheres to a renovating perspective of health - as though the authors adhere to a more critical movement of thought while, however, lacking the public presentation of the translation of this political will into a thought that articulates the empirical and theoretical dimensions. They, thus, incur in the same problems as the other texts we have analyzed: they list general (concretefactual) characteristics of human beings, but with a certain view of the social which fragments them into more empirical, practical dimensions, which hinders the articulation with the social that explain these very fragments that compose life.

These studies have in common the a priori use of an existing definition of health, or the use of insufficiently explained references with regard to their relationship with what is health, often also maintaining an abstract reflection without verifying its correspondence to an empirical reality. On the other hand, they coincide in the adoption of a critical position with regard to the way health is treated by biomedicine. In seeking to distance themselves from biomedicine, they adopt a critical position as a social movement to be followed, but that is not a concept. Schraiber (2015, p. 35) calls this movement an ethical-political engagement "in which the researcher subject delimits their object due to the social, political and historical importance attributed to it", but also states that this same movement at times ends up being based on the principle that "the politically engaged does not require the theoreticalconceptual contribution and that this contribution does not intensify the politically engaged". Thus, we may consider that these definitions of health are not a concept, but an ideal, a motto.

\section{The concept of health in Collective Health: health as ongoing conceptual constructions}

The remaining studies discussed the concept of health based on existing definitions, seeking to verify positive and negative aspects in order to produce a more qualified formulation of the object health, while others sought to create a new conception based on their theoretical references.

Coelho and Almeida Filho (1999) and Arreaza (2012) critically analyze Canguilhem's conception of health, while Coura (1992, p. 336), despite not basing 
his reflections on that author, arrives at a very similar conception of health: "man's adaptation to the environment, preserving his physical, functional, mental and social integrity", with adaptation defined as an active dynamic adjustment.

Canguilhem's (2012) definition of health seeks to understand how life has been lived, articulating everyday life with society's rules. It seems to us to be the closest to our conception of what is a concept. It considers disease as impeded living with regard to the way life in society flows, that is, a practical (concrete particular) obstacle to the way in which, historically and socially, social relationships are occurring within a limited time and place; and health as permitted living, that is, living concretely exercised relative to that social normativity. Thus, there is no definition of health or disease outside of social normativity, as a generic, universal abstract that is independent of social and historical reality. Therefore, and at the same time, it is not possible to define health and disease only by considering the normal and the pathological based on the anatomical-functional irregularities of biomedicine.

Nonetheless, the studies we analyze still seem to lack both the particular-concrete examination of some social reality in which living is impeded - thus enabling them to verify the functionality of this construction of health for considering and explaining empirical situations - and an analysis that regards the social and its normativity as a tense and contradictory whole with regard to the distinct class positions in the way life in society flows. Thus, it would be possible not only to understand this way in which life flows, but also why this life is being prevented, or not, from being fully lived, or rather, why, despite all the social violence to which individuals are subjected, they still need to continue to walk this path.

In addition to these studies that were based on social normativity, Ayres (2007, p. 60) argues that the concepts of health and disease refer to practical and instrumental interests, respectively, in the rational formulation of lived experiences of healthillness-care processes, and belong to distinct rationalities. He concludes that health means "the continuous and socially-shared search for means to conveniently avoid, manage or overcome illness processes, in their condition as indicators of obstacles faced by individuals and collectivities to carrying out their projects of happiness".

Nogueira (2011, p. 264) argues that health is not located in life, in physical organs, or even in the mind, because it is not a state or condition that one finds or measures based on signs, symptoms and biochemical alterations in the body. $\mathrm{He}$ 
conceptualizes health as follows: "The essence of health is identified with the very extatic essence of the Dasein, and is the basis for all the 'healthy' potentialities of the Dasein in the world".

Ayres's (2007) study, despite being based on Heidegger and Gadamer's hermeneutics, seems to us very similar to Canguilhen's definition of health. By understanding health not as the logical opposite of disease - because they do not belong to the same rationality -, the author establishes a parallel with Canguilhem, in that health and disease are not each other's opposite, but different norms of how to go through life. Considering that, to the latter, health corresponds to an unimpeded way of living, we can establish a relationship with Ayres (2007), who seeks an interaction with care, the idea that health is a way of living in which there are means to avoid, manage or overcome another way of living the impeded life - illness. Similarly, it seems to us that, just as in Canguilhem, whoever uses this conception must take the next step, seeking to determine not only what the means are, but why these are the means and why, largely, these means are not available to the population as a whole in a capitalist society.

Nogueira (2011), also working from Heidegger's hermeneutics, takes a different path. According to the author (2011, p. 260) "the Dasein does not understand itself, nor can it be analyzed as if it were a property of a being given in actuality (Wirklichkeit), but only through the possibility that he himself is at every moment", that is, the Dasein does not correspond to the lived, but to the potential for living. And, based on the explanation of Dasein, he places health in the same condition: the essence of health is the essence of the Dasein, that is, of "being there", being in the lived life of the human being. Thus highlighting health more from the perspective of the human, the human's relationship with social normativity and its internal tensions with regard to social classes remain under-discussed in this article.

On the other hand, all the articles in this group, situated as essays, seem to us to be an ongoing construction, that is, not yet completed, but that may offer important paths toward the conceptual construction of health.

\section{Partial approximations to the essence of the health object}

The health definitions, though diverse, are largely convergent and make up, as we have shown, a set of notions. According to Ilyenkov (2008), a notion is, firstly, 
a form of social memory represented through discourse, through language. In his words (2008, p. 43):

If an individual has acquired a notion of a thing from other individuals who observed it directly, the acquired form of consciousness of it is precisely that which he would have received had he contemplated this thing with his own eyes. Having a notion means having a socially comprehended (that is, expressed in speech or capable of being expressed in speech) contemplation. Neither I nor some other individual form a concept of some thing if I, through speech, observe this thing through the eyes of another individual or this other individual contemplates it through my eyes. We engage in mutual exchange of notions. A notion is precisely that-verbally expressed contemplation.

Thus, the contemplation of the sensory world and the notion are ways of expressing this world, which make use of the empirical form of knowledge. The individual contemplation that is socially perceived will always be contained within the notion, which makes transmitting this notion through discourse possible, meaning the transmission of the socially individual contemplation itself. Thus, contemplation and notion are only the first sensory stage of knowledge. The notion is a partial approximation of knowledge of an object.

But in no way can notions be considered false, totally decoupled from reality. They must be viewed as partial explanations or understandings and it must be acknowledged that, to individuals, in general, going through life knowing its objects through notions instead of concepts is not a problem: life is lived in the dayto-day based on notions of things. However, when one studies an object (seeking to transform it), one must carry out deeper approximations than the mere notion.

However, as we have also seen, most studies were situated within this realm of formulation. According to Marx and Engels (2009, p. 30), the researcher "necessarily lights on things which contradict his consciousness and feeling, which disturb the harmony he presupposes, the harmony of all parts of the sensuous world and especially of man and nature". In order to apparently overcome this contradiction between his thought and the real world, the researcher seeks refuge in a "double perception, a profane one which only perceives the "flatly obvious" and a higher,philosophical, one which perceives the "true essence" of things":

He does not see how the sensuous world around him is not a thing given direct from all eternity, remaining ever the same, but the product of industry and of the state of society; and, indeed, in the sense that it is an historical product, the result of the activity of a whole succession of generations, each standing on the shoulders of the preceding one, 
developing its industry and its intercourse, modifying its social system according to the changed needs. (MARX; ENGELS, 2009, p. 30).

Thus, notions of health set a representation of it in place of health re-articulated to the social-historical, leading researchers to only look at health through its concretefactual characteristics. Without a clear signification, they end up with a pragmatic and operational notion (AROUCA, 2003), which is actually used to naturalize the determinations, especially the social determinations, of human health.

The same goes for nutrition, housing, education, environment, employment, leisure, access to health services, among others: they are all characteristics that are part of the way life flows in society; but they do not explain themselves and, because they do not tell us anything specific about themselves, they do not tell us anything specific about what is health.

In Collective Health, we see that there is an attempt to create formulations articulated to the social and the historical. However, in most cases, a full critique is not reached. Some elements of this logic connected to the concrete factual - and that are presented as a more formal rationality than the dialectics of understanding this concrete factual as actual sociality and historicity - are reconsidered. But there is great difficulty in overcoming studies' empirical dimension in favor of a deeper construction, as we understand theoretical-conceptual formulations to be. ${ }^{1}$

\section{References}

ALMEIDA, D. T.; TREVISAN, E. R. Estratégias de intervenção da Terapia Ocupacional em consonância com as transformaçóes da assistência em saúde mental no Brasil. Interface. Botucatu, v. 15, n. 36, p. 299-308, 2011.

AROUCA, S. O dilema preventivista: contribuição para a compreensão e crítica da medicina preventiva. São Paulo: Editora UNESP; Rio de Janeiro: Editora da Fiocruz, 2003.

ARREAZA, A. L. V. Epidemiologia crítica: por uma práxis teórica do saber agir. Ciência \& Saúde Coletiva, v. 17, n. 4, p. 1001-1013, 2012.

AUGUSTO, V. G. et al. Promoção de saúde em unidades básicas: análise das representações sociais dos usuários sobre a atuação da fisioterapia. Ciência \& Saúde Coletiva, v. 16, supl. 1, p. 957-963, 2011.

AYRES, J. R. C. M. Uma concepção hermenêutica de saúde. Physis: Revista de Saúde Coletiva. Rio de Janeiro, v. 17, n. 1, p. 43-62, 2007. 
BEZERRA, A. F. B.; ESPÍRITO SANTO, A. C. G.; BATISTA FILHO, M. Concepções e práticas do agente comunitário na atenção à saúde do idoso. Revista de Saúde Pública. São Paulo, v. 39, n. 5, p. 809-815, 2005.

BRUGNEROTTO, F.; SIMÕES, R. Caracterização dos currículos de formação profissional em Educação Física: um enfoque sobre saúde. Physis: Revista de Saúde Coletiva. Rio de Janeiro, v. 19, n. 1, p. 149-172, 2009.

BYDLOWSKI, C. R.; WESTPHAL, M. F.; PEREIRA, I. M. T. B. Promoção da saúde. Porque sim e porque ainda não! Saúde e Sociedade. São Paulo, v. 13, n. 1, p. 14-24, 2004.

CANGUILHEM, G. O normal e o patológico. Rio de Janeiro: Forense Universitária, 2012.

CIÊNCIA \& SAÚDE COLETIVA. Importância das Revistas de Saúde Pública/Saúde Coletiva para o SUS e para a Ciência Brasileira. Rio de Janeiro, v. 20, n. 7, 2015.

COELHO, M. T. Á. D.; ALMEIDA FILHO, N. Normal-patológico, saúde-doença: revisitando Canguilhem. Physis: Revista de Saúde Coletiva. Rio de Janeiro, v. 9, n. 1, p. 13-36, 1999.

COSTA, M. L.; BERNARDES, A. G. Produção de Saúde como Afirmação de Vida. Saúde e Sociedade. São Paulo, v. 21, n. 4, p. 822-835, 2012.

COURA, J. R. Endemias e meio ambiente no século XXI. Cadernos de Saúde Pública. Rio de Janeiro, v. 8, n. 3, p. 335-341, 1992.

CZERESNIA, D. The concept of health and the difference between prevention and promotion. Cad. Saúde Pública. Rio de Janeiro, v. 15, n. 4, p. 701-709, 1999.

DALLARI, S. G. Controle judicial da política de assistência farmacêutica: direito, ciência e técnica. Physis: Revista de Saúde Coletiva. Rio de Janeiro, v. 20, n. 1, p. 57-75, 2010.

DELFINO, M. R. R. et al. O processo de cuidar participante com um grupo de gestantes: repercussóes na saúde integral individual-coletiva. Ciência \& Saúde Coletiva. Rio de Janeiro, v. 9, n. 4, p. 1057-1066, 2004.

FEIO, A.; OLIVEIRA, C.C. Confluências e divergências conceituais em educação em saúde. Saúde e Sociedade. São Paulo, v. 24, n. 2, p. 703-715, 2015.

FIGUEIRA, T. R. et al. Percepçôes e açôes de mulheres em relação à prevenção e promoção da saúde na atenção básica. Revista de Saúde Pública. São Paulo, v. 43, n. 6, p. 937-943, 2009.

FREIRE JÚNIOR, R. C.; TAVARES, M. F. L. A saúde sob o olhar do idoso institucionalizado: conhecendo e valorizando sua opinião. Interface. Botucatu, v. 9, n. 16, p. 147-158, 2005.

HOBSBAWM, E. Era dos extremos: o breve século XX: 1914-1991. São Paulo: Companhia das Letras, 2011.

ILYENKOV, E. V. The dialectics of the abstract and the concrete in Marx's Capital. Delhi: Aakar Books, 2008. 
KOSIK, K. A dialética do concreto. Rio de Janeiro: Paz e Terra, 2011.

LEFÈBVRE, H. Lógica formal. Lógica dialética. Rio de Janeiro: Civilização Brasileira, 1983.

LOPES, F. Para além da barreira dos números: desigualdades raciais e saúde. Cadernos de Saúde Pública. Rio de Janeiro, v. 21, n. 5, p. 1595-1601, 2005.

MARCONDES, W. B. A convergência de referências na promoção da saúde. Saúde e Sociedade. São Paulo, v. 13, n. 1, p. 5-13, 2004.

MARTINS, M. F. S. V. Imagens construídas em torno da gravidez. Ciência \& Saúde Coletiva. Rio de Janeiro, v. 15, p. 1369-1375, 2010.

MARX, K. Contribuição à crítica da economia política. São Paulo: Expressão Popular, 2008.

MARX, K. O capital: crítica da economia política. Livro I: o processo de produção do capital. São Paulo: Boitempo, 2013.

MARX, K.; ENGELS, F. A ideologia alemã: crítica da mais recente filosofia alemã em seus representantes Feuerbach, B. Bauer e Stirner, e do socialismo alemão em seus diferentes profetas (1845-1846). São Paulo: Boitempo, 2009.

MATUMOTO, S.; MISHIMA, S. M.; PINTO, I. C. Saúde Coletiva: um desafio para a enfermagem. Cadernos de Saúde Pública. Rio de Janeiro, v. 17, n. 1, p. 233-241, 2001.

NOGUEIRA, R. P. Extensão fenomenológica dos conceitos de saúde e enfermidade em Heidegger. Ciência \& Saúde Coletiva. Rio de Janeiro, v. 16, n. 1, p. 259-266, 2011.

OLIVEIRA, M. M.; PINTO, I. C. Percepção das usuárias sobre as ações de Prevenção do Câncer do Colo do Útero na Estratégia Saúde da Família em uma Distrital de Saúde do município de Ribeirão Preto, São Paulo, Brasil. Rev. Bras. Saúde Matern. Infant. Recife, v. 7, n. 1, p. 31-38, 2007.

OLIVEIRA, S. K. M. et al. Autopercepção de saúde em quilombolas do norte de Minas Gerais, Brasil. Ciência \& Saúde Coletiva. Rio de Janeiro, v. 20, n. 9, p. 2879-2890, 2015.

OSMO, A.; SCHRAIBER, L. B. O campo da saúde coletiva no Brasil: definições e debates em sua constituição. Saúde e Sociedade. São Paulo, v. 24, supl.1, p. 205-218, 2015.

PAIM, J. S.; ALMEIDA FILHO, N. Saúde coletiva: uma "nova saúde pública” ou campo aberto a novos paradigmas? Rev. Saúde Pública. São Paulo, v. 32, n. 4, p. 299-316, 1998.

PEREIRA, I. M. T. B.; WESTPHAL, M. F.; STEWIEN, G. T. M. Percepções do médicochefe a respeito de atividades educativas em Postos de Assistência Médica. Revista de Saúde Pública. São Paulo, v. 25, n. 4, p. 306-314, 1991.

PRATES, J. G. et al. A concepção dos enfermeiros de serviços de urgência e emergência sobre o processo saúde-doença na assistência aos usuários de substâncias psicoativas. Saúde em Debate. Rio de Janeiro, v. 38, n. 101, p. 318-327, 2014. 
SANTOS, W. J.; GIACOMIN, K. C.; FIRMO, J. O. A. Alteridade da dor nas práticas de Saúde Coletiva: implicações para a atenção à saúde de pessoas idosas. Ciência \& Saúde Coletiva. Rio de Janeiro, v. 20, n. 12, p. 3713-3721, 2015.

SCHRAIBER, L. B. Engajamento ético-político e construção teórica na produção científica do conhecimento em saúde coletiva. In: BAPTISTA, T. W. F.; AZEVEDO, C. S.; MACHADO, C. V. (Orgs.). Políticas, planejamento e gestão em saúde: abordagens e métodos de pesquisa. Rio de Janeiro: Editora da Fiocruz, 2015, p. 33-57.

SCLIAR, M. História do conceito de saúde. Physis: Revista de Saúde Coletiva. Rio de Janeiro, v. 17, n. 1, p. 29-41, 2007.

SEGRE, M.; FERRAZ, F. C. O conceito de saúde. Revista de Saúde Pública. São Paulo, v. 31, n. 5, p. 538-542, 1997.

SHIMIZU, H. E. et al. A estrutura das representações sociais sobre saúde e doença entre membros de movimentos sociais. Ciência \& Saúde Coletiva. Rio de Janeiro, v. 20, n. 9, p. 28992910, 2015.

SILVA, C. O.; RAMMINGER, T. O trabalho como operador de saúde. Ciência \& Saúde Coletiva. Rio de Janeiro, v. 19, n. 12, p. 4751-4758, 2014.

SILVA, S. M.; RAMOS, M. Z. Profissionais de saúde de um serviço de emergência hospitalar: discursividades em torno do cuidado. Physis: Revista de Saúde Coletiva. Rio de Janeiro, v. 24, n. 3, p. 693-714, 2014.

SIQUEIRA, M. M.; MORAES, M. S. Saúde coletiva, resíduos sólidos urbanos e os catadores de lixo. Ciência \& Saúde Coletiva. Rio de Janeiro, v. 14, n. 6, p. 2115-2122, 2009.

STANGA, A. C.; REZER, R. Concepçóes de saúde, trabalho docente e o Pró-Saúde: nos caminhos da hermenêutica... Physis: Revista de Saúde Coletiva. Rio de Janeiro, v. 25, n. 2, p. 593-614, 2015.

TORRES, M. F. M.; CARVALHO, F. R.; MARTINS, M. D. Estudo comparativo da concepção de saúde e doença entre estudantes de odontologia e ciências sociais de uma universidade pública no Estado do Rio de Janeiro. Ciência \& Saúde Coletiva. Rio de Janeiro, v. 16, p. 1409-1415, 2011.

VIGOTSKI, L. S. A construção do pensamento e da linguagem. São Paulo: WMF Martins Fontes, 2009.

\section{Notas}

${ }^{1}$ M. J. de Souza e Silva, L. B. Schraiber and A. Mota contributed substantially to the article's conception and were all involved in data collection, analysis and interpretation, manuscript preparation and revision and approval of the final version for publication. 


\section{Resumo}

O conceito de saúde na Saúde Coletiva: contribuiçóes a partir da crítica social e histórica da produção científica

A presente pesquisa teve como objetivo compreender qual é o conceito de saúde dentro da Saúde Coletiva. Nossa análise parte do marxismo como referencial teórico, tanto para definir o que é um "conceito" quanto para compreender o pensamento crítico da Saúde Coletiva. Como pesquisa empírica, usou-se a produção bibliográfica dos principais periódicos que reúnem publicaçôes da Saúde Coletiva enquanto área de conhecimento, o que resultou em 34 artigos que tratavam, de alguma forma, do conceito de saúde, mesmo que não fosse o objeto principal do trabalho. Dessa análise identificamos ao menos três distintas modalidades de definiçóes, que variaram tanto na base referencial usada para apreender e analisar realidades empíricas concernentes à saúde quanto na conceituação de social que poderia estar nessa análise - também se identificando que os artigos mais oscilaram entre uma produção estritamente descritiva dessas realidades empíricas e ensaios estritamente teóricos do que produziram um particular concreto (empírico) pensado com base na definiçáo de social eleita. Concluiu-se que dentro da Saúde Coletiva o conceito de saúde tem sido tomado, em grande parte, ou como noção (uma aproximação parcial do objeto) ou como um lema, a partir de um engajamento ético-político que acaba relegando a contribuição teórico-conceitual a segundo plano.

> Palavras-chave: Saúde Coletiva; formação de conceito; saúde; conhecimento, trabalho. 